\title{
The Rod Pathway of the Microbat Retina Has Bistratified Rod Bipolar Cells and Tristratified AII Amacrine Cells
}

\author{
Brigitte Müller, Elisabeth Butz, Leo Peichl, and Silke Haverkamp \\ Max Planck Institute for Brain Research, 60528 Frankfurt/Main, Germany
}

We studied the retinal rod pathway of Carollia perspicillata and Glossophaga soricina, frugivorous microbats of the phyllostomid family. Protein kinase $\mathrm{C} \alpha(\mathrm{PKC} \alpha)$ immunolabeling revealed abundant rod bipolar cells (RBCs) with axon terminals in the innermost sublamina of the inner plexiform layer (IPL), which is typical for mammals. Extraordinarily, the RBC axons showed additional synaptic contacts in a second sublamina further out in the IPL. Dye injections of PKC $\alpha$-prelabeled RBCs of $C$. perspicillata confirmed the bistratified axon morphology. The functional partition of the IPL into $\mathrm{ON}$ and OFF sublayers was shown by using antibodies against vesicular glutamate transporter 1 [labeling all $\mathrm{ON}$ and OFF bipolar cell (BC) axon terminals] and G-protein $\gamma 13$ (labeling all ON BCs). The ON sublayer occupied $75 \%$ of the IPL thickness, including both strata of the RBC axons. RBC output onto putative AII amacrine cells (ACs), the crucial interneurons of the rod pathway, was identified by calretinin, $\mathrm{PKC} \alpha$, and CtBP2 triple immunolabeling. Dye injections of calretininprelabeled ACs revealed tristratification of the AII ACs corresponding to the bistratified RBCs. Triple immunolabeling for PKC $\alpha$, nitric oxide synthetase (NOS), and either $\mathrm{GABA}_{\mathrm{C}}$ or CtBP2 indicated GABAergic feedback onto RBCs via NOS-immunoreactive ACs. AII output analysis showed glycineric synapses with glycine receptor $\alpha 1$ expression between AII cells and OFF cone BCs and connexin 36-labeled gap junctions between AII cells and ON cone BCs. We conclude that microbats have a well developed rod pathway with great similarities to that of other mammals, but with an unusual IPL stratification pattern of RBCs and AIIs.

\section{Introduction}

The eyes of microchiropteran bats are small, and their retinae are rod dominated (Müller et al., 2009). Whereas microbats are able to orient at complete darkness by echolocation, vision plays an important role during their flights between daytime roosts and feeding grounds and during migration over longer distances (Griffin, 1970; Suthers, 1970; for review, see Eklöf, 2003). At dusk and dawn and on brightly moonlit nights, many bat species use visual cues for long-range orientation and navigation. Vision also plays a role in predator avoidance and prey detection (Altringham and Fenton, 2003; Eklöf and Jones, 2003). Glossophaga soricina and Carollia perspicillata are phyllostomid microbats feeding on fruit, nectar, or pollen. Compared with insectivorous microbats, frugivorous microbats have larger eyes and larger visual brain regions (Barton et al., 1995; Barton and Harvey, 2000).

In mammals, scotopic vision is mediated by rod photoreceptors and photopic vision by cone photoreceptors. Rods and cones are contacted by distinct types of bipolar cells (BCs) that can be subdivided into several morphological types of cone BCs and one

\footnotetext{
Received April 30, 2012; revised 0ct. 1, 2012; accepted 0ct. 26, 2012.

Author contributions: B.M., L.P., and S.H. designed research; B.M. and E.B. performed research; B.M., E.B., and S.H. analyzed data; B.M., L.P., and S.H. wrote the paper.

This work was supported by Deutsche Forschungsgemeinschaft Grant MU 2338/1. Animals were kindly provided by Manfred Kössl (Goethe University, Frankfurt/Main, Germany) and the late Otto von Helversen (FriedrichAlexander University, Erlangen, Germany). We thank Driss Benzaid for help with the reconstructions, Sammy Lee for help with confocal images, and Gilles Laurent for help with financial support.

The authors declare no competing financial interests.

Correspondence should be addressed to Brigitte Müller, Max Planck Institute for Brain Research, Deutschordenstr. 46,60528 Frankfurt/Main, Germany. E-mail: brigitte.mueller@brain.mpg.de.

DOI:10.1523/JNEUROSCI.2072-12.2013

Copyright $\odot 2013$ the authors $\quad 0270-6474 / 13 / 331014-10 \$ 15.00 / 0$
}

type of rod bipolar cell (RBC) (Ghosh et al., 2004). Functionally, $\mathrm{BC}$ are subdivided into $\mathrm{ON}$ and $\mathrm{OFF} \mathrm{BCs}$ according to their light response (Saito, 1987); the RBC is an ON cell (Dacheux and Raviola, 1986).

All RBCs studied to date have a similar morphology with axons that run through the inner plexiform layer (IPL) and end in large lobular terminals at the border of the IPL and ganglion cell layer (Ramón y Cajal, 1893). Cone BCs contact ganglion cells directly, whereas RBCs use an intermediary. They synapse onto a narrow-field bistratified amacrine cell (AC), the AII AC (Famiglietti and Kolb, 1975), that in turn forms glycinergic chemical synapses with OFF cone BCs and gap junctions with ON cone BCs (Strettoi et al., 1992), transferring signals of opposite polarity to $\mathrm{ON}$ and OFF ganglion cells.

Microchiropteran bats have, in addition to a majority of rods, a significant cone population (2-5\%) and hence the basis for daylight and color vision (Müller et al., 2009). However, nothing is known about bat BCs, and only certain types of ACs have been described up to now. Dopaminergic and GABAergic ACs were found in four phyllostomid species (Studholme et al., 1987). Furthermore, in the greater horseshoe bat, AII-like ACs were labeled by antisera against calcium-binding proteins (Jeon et al., 2007). The existence of AII cells suggests that the bat retina possesses the typical constituents of the mammalian rod pathway.

The aim of the present study was to elucidate whether the phylogenetically old clade of bats indeed has such a typical mammalian rod pathway. We revealed the morphology of bat RBCs and AII ACs by immunocytochemistry and intracellular dye injections. The synaptic contacts of RBCs with AII cells and of AII cells with $\mathrm{OFF}$ and $\mathrm{ON}$ cone BCs were identified by immunola- 
beling. The results indicate a conventional mammalian rod pathway, but they also reveal a unique peculiarity in the morphology and connectivity of bat RBCs that may be of significance for retinal performance during nocturnal vision.

\section{Materials and Methods}

Tissue preparation

We examined adults of either sex of the phyllostomid bat species $C$. perspicillata $(n=13)$ and G. soricina $(n=2)$. Animals came from breeding colonies at Goethe University (Frankfurt/Main, Germany) and at Friedrich-Alexander University (Erlangen, Germany). Animals were deeply anesthetized by isoflurane (CuraMED Pharma) and decapitated. The eyes were enucleated, and the anterior part was removed. All procedures for animal handling and killing complied with the NIH Principles of Laboratory Animal Care and the corresponding German laws.

For immunocytochemistry on cryostat sections, the posterior eyecup was immersion fixed in $4 \%$ paraformaldehyde (PA) in $0.1 \mathrm{~m}$ phosphate buffer (PB; pH 7.4) for 15 or $30 \mathrm{~min}$ at room temperature. After washing in $\mathrm{PB}$, either the isolated retina or the whole eyecup was cryoprotected in graded sucrose solutions $(10,20$, and $30 \%$ in PB) and frozen in embedding medium (Jung). Vertical sections $(14-16 \mu \mathrm{m})$ were cut and collected on superfrost slides.

For intracellular dye injections of RBCs and AII ACs, enucleated eyes were transferred to oxygenated Ames medium (Sigma-Aldrich) and opened by an encircling cut. The retina was separated from pigment epithelium and sclera, embedded in 2\% low melting agar (2hydroxymethyl agarose, A4018; Sigma-Aldrich), mounted on a vibratome (D.S.K. Microslicer, DTK-1000; Ted Pella), and cut into $150 \mu \mathrm{m}$ sections. After another $10 \mathrm{~min}$ in Ames medium, sections were fixed in $4 \% \mathrm{PA}$ in $\mathrm{PB}$ at $4^{\circ} \mathrm{C}$ for $15 \mathrm{~min}$. Subsequently, they were transferred to $\mathrm{PB}$, processed for free-floating immunocytochemistry, and fixed for another $30 \mathrm{~min}$ in $4 \% \mathrm{PA}$.

\section{Immunocytochemistry}

Antibodies. For labeling RBCs, three different antibodies against protein kinase $\mathrm{C} \alpha(\mathrm{PKC} \alpha)$ were used. They were raised in rabbit $(1: 10,000$, P4334; Sigma-Aldrich), mouse (1:100, K01107M; Meridian Life Science), and goat (1:1000, sc-208-G; Santa Cruz Biotechnology). For labeling ribbon synapses, a rabbit antiserum against the $\mathrm{C}$-terminal binding protein-2 (CtBP2) was used (1:4000, catalog \#193 003; Synaptic Systems). For labeling AII ACs, rabbit anti-calretinin (1:2000, PV-28; Swant) and mouse anti-calretinin (1:1000, MAB1568; Millipore) were used. For labeling a subset of OFF and ON cone BCs, rabbit antirecoverin (1:2000, AB5585; Millipore) was used. ON BCs were labeled with rabbit antiserum against G-protein $\gamma 13(\mathrm{G} \gamma 13)$ (1:1000; kind gift from R. F. Margolskee, Mount Sinai School of Medicine, New York, NY). $\mathrm{BC}$ axon terminals were immunostained with guinea pig anti-vesicular glutamate transporter 1 (vGluT1) (1:50,000, AB5905; Millipore). ACs containing nitric oxide synthetase (NOS) were labeled by rabbit antiNOS (1:2000, N 7280; Sigma-Aldrich). Cholinergic ACs were labeled by goat anti-choline acetyltransferase (ChAT; 1:200, AB144P; Millipore). A mouse monoclonal antibody against glycine receptor $\alpha 1$ subunit was used (1:100, mAb2b; kind gift from H. Betz, Max Planck Institute for Brain Research, Frankfurt, Germany). A rabbit polyclonal antiserum against the $\mathrm{GABA}_{\mathrm{C}}$ receptor $\rho 1$ subunit was used (1:100) (Enz et al., 1996). For labeling gap junctions, rabbit anti-connexin 36 (Cx36; 1:100, 36-4600; Zymed) and mouse anti-connexin 36 (1:100, 37-4600; Zymed) were used.

Tissue processing. Cryostat sections were preincubated in $\mathrm{PB}$ containing $10 \%$ normal donkey serum (NDS), $1 \%$ bovine serum albumin, and $0.5 \%$ Triton X-100 for $1 \mathrm{~h}$. Antibodies were diluted in PB containing 3\% NDS and $0.5 \%$ Triton X-100. Sections were incubated overnight in primary antibodies, followed by a wash and a $1 \mathrm{~h}$ incubation in secondary antibodies that were conjugated to Alexa 488 (Invitrogen), Cy3, or Cy5 (Dianova). After a final wash, sections were coverslipped with AquaPoly/Mount (Polysciences Europe). For double and triple immunolabeling, the respective primary and secondary antibodies were applied as a mixture. For triple labeling with PKC $\alpha(\mathrm{ms})$, NOS (rb), and either $\mathrm{GABA}_{\mathrm{C}}(\mathrm{rb})$ or CtBP2 $(\mathrm{rb})$, it was necessary to use two primary antibodies of the same species. In this case, cryosections were first incubated with the NOS antibody at a dilution too low for direct detection by a secondary antibody (1:200,000 instead of 1:2000). The staining was visualized by a secondary antibody raised in goat and a tertiary donkey anti-goat antibody carrying the same fluorophore. After the application of the secondary and tertiary antibodies, a mixture of the other two primary antibodies was applied, and the antibody labeling was performed as described above.

For prelabeling of vibratome sections, antibodies were diluted in $\mathrm{PB}$ containing 3\% NDS and $0.3 \%$ Tween. The incubation time for primary and secondary antibodies was $1 \mathrm{~h}$ each, with three washes in $\mathrm{PB}$ after each incubation step.

\section{Intracellular injections of DiI}

For intracellular injections of individual RBCs and AII ACs with the fluorescent lipophilic tracer DiI (D-282; Invitrogen), using the method of Kao and Sterling (2003), retinal slices were mounted in the injection chamber and fixed by the nylon strings of a "micro-harp." Sharp microelectrodes were pulled from borosilicate glass tubing (Hilgenberg) and filled with $0.5 \%$ DiI solution in $100 \%$ ethanol. The dye was injected into $\mathrm{PKC} \alpha$-prelabeled BCs and calretinin-prelabeled ACs with $1 \mathrm{nA}$ positive current for $3 \mathrm{~min}$. After injection, slices were kept in $\mathrm{PB}$ at $4^{\circ} \mathrm{C}$ overnight for diffusion of the dye into the fine processes. Injected slices were mounted on glass slides and coverslipped with Aqua-Poly/Mount, and filled cells were analyzed by confocal microscopy.

\section{Microscopic analysis}

Some fluorescent specimens were viewed with an Axioplan 2 microscope equipped with epifluorescence (Carl Zeiss). Micrographs were taken using a CCD camera and the Zeiss Axiovision LE software. Confocal images were taken using either a Zeiss LSM 5 Pascal or an Olympus FV1000 confocal microscope, both equipped with argon and HeNe lasers. Highresolution scanning of image stacks was performed with a Plan-Apochromat $63 \times / 1.40$ (Zeiss) or aUPlanSApo $60 \times / 1.35$ (Olympus) oil-immersion objective, respectively, at $1024 \times 1024$ pixels and a $z$-axis increment of $0.3 \mu \mathrm{m}$. For analysis of injected cells, a stack of $12-30$ sections was taken $(1 \mu \mathrm{m} z$-axis step size). The cell's contacts were analyzed by scrutinizing the individual sections. The neurites were reconstructed by collapsing the stacks into a single plane. Brightness and contrast of the final images were adjusted using Adobe Photoshop CS2.

\section{Results}

\section{Bistratified morphology of rod bipolar cells}

RBCs were analyzed by immunohistochemistry and dye injections. We used PKC $\alpha$ as a common marker for RBCs (Greferath et al., 1990) to label retinal sections of the phyllostomid microbat species $C$. perspicillata and G. soricina. PKC $\alpha$-labeled cryostat sections showed an abundant population of immunoreactive RBCs (Fig. 1 $A, C$ ). The somata were closely packed in the outer half of the inner nuclear layer (INL). The dendrites densely branched in the outer plexiform layer (OPL); the axons ran through the entire IPL and terminated in characteristic clubshaped varicose swellings in sublaminae S4 and S5. A second layer of axonal swellings was obvious in sublamina S2 of the IPL. Close examination with high-power light microscopy indicated a single type of PKC $\alpha$-immunoreactive (ir) BCs.

Intracellular injections of BCs with the fluorescent dye DiI in unlabeled vertical slices of microbat retina frequently revealed BCs with the morphology of PKC $\alpha$-ir cells and varicose axon terminals in S4 and S5 (Fig. 1 E, F). The axons had clear additional varicosities in S2, either directly within the axon or at the end of a short branch. DiI injections in vertical slices pre-labeled with PKC $\alpha$ antiserum confirmed the bistratified morphology of the bat RBCs (Fig. $1 G-K$ ). In all cases the double-labeled bipolar cells showed varicosities in S4 and S5 as well as in S2. DiI-injected bipolar cells had a bushy dendritic tree in the OPL that extended to the outer nuclear layer (ONL; Fig. $1 H, J$ ). This indicates the innervation of numerous rod spherules and is a conspicuous feature of mammalian RBCs. 

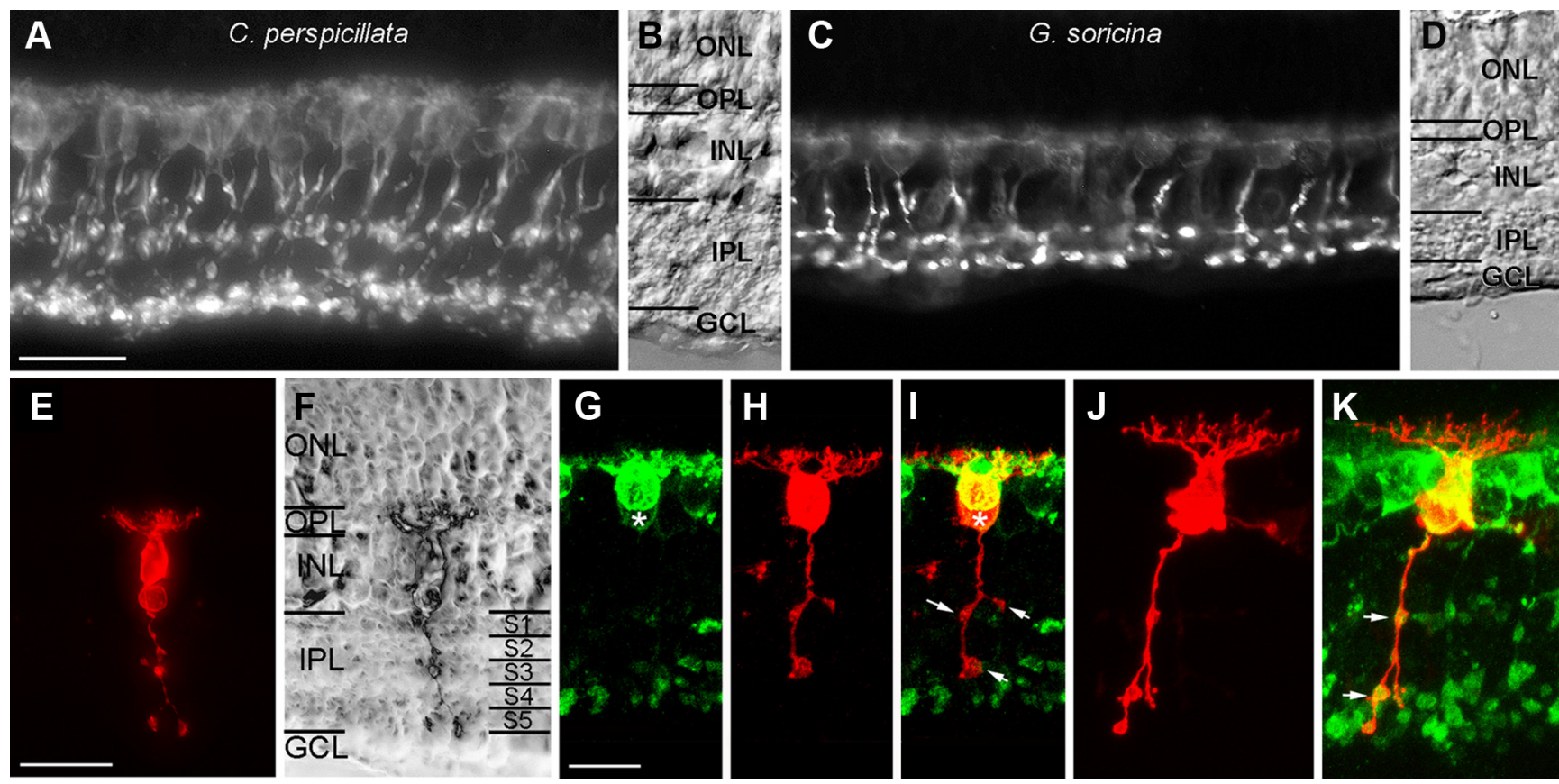

Figure 1. $\boldsymbol{A}, \boldsymbol{C}$, Vertical cryostat sections of $C$. perspicillata $(\boldsymbol{A})$ and $\mathrm{G}$. soricina $(\boldsymbol{C})$ retina, immunolabeled for PKC $\alpha$. The cell bodies are located in the outer half of the INL, the dendritic branches in the OPL extend to the ONL border, and the axons terminate deep in the IPL close to the GCL. In the outer third of the IPL, additional PKC $\alpha$-ir varicosities form a second stratum in S2. $\boldsymbol{B}, \boldsymbol{D}$, Retinal layers of sections $\boldsymbol{A}$ and $\boldsymbol{C}$, respectively, by DIC optics. Retinal thickness differs between the two species. $\boldsymbol{E}, \boldsymbol{H}, \boldsymbol{J}$, Individual Dil-injected RBCs in vertical vibratome slices of $\boldsymbol{C}$. perspicillata retina. $\boldsymbol{F}$, Retinal slice in DIC optics with a digitally superimposed contour of a Dil-injected RBC. The IPL is divided into five strata, S1-S5. G, Slices in $\boldsymbol{H}$ and $\boldsymbol{J}$ were prelabeled for PKC $\alpha$. I, $\boldsymbol{K}$, Merge of Dil-injected RBCs and PKC $\alpha$ staining, where varicose presumed synaptic sites are marked by arrows. Asterisk in $\mathbf{G}$ and $I$ indicates the cell body of the PKC $\alpha$-ir RBC that was injected with Dil. The filled round soma below the RBC soma in $\boldsymbol{E}$ is a cell without processes injected en passant. The filled process to the left of the cell in $\boldsymbol{H}$ and to the right of the soma in $\boldsymbol{J}$ belongs to another cell. $\mathrm{GCL}$, Ganglion cell layer. Scale bars: $\boldsymbol{A}-\boldsymbol{D}$ (in $\boldsymbol{A}), \boldsymbol{E}, \boldsymbol{F}$ (in $\boldsymbol{E}$ ), $20 \mu \mathrm{m} ; \boldsymbol{G}-\boldsymbol{K}$ (in $\boldsymbol{G}), 10 \mu \mathrm{m}$.

\section{ON/OFF subdivision of the IPL}

The IPL usually is subdivided into five bands of equal thickness. In mouse retina and several other species, the OFF sublayer includes $\mathrm{S} 1$ and $\mathrm{S} 2$ and the ON sublayer includes S3-S5 (Ghosh et al., 2004). G $\gamma 13$ and vGluT1 antibodies are common markers to reveal the functional subdivision of the IPL; G $\gamma 13$ labels all ON BCs, and vGlut1 labels all ON and OFF BC axon terminals (Huang et al., 2003; Ghosh et al., 2004; Puller et al., 2011). Figure $2 A$ shows vGluT1 immunostaining in the microbat retina. BC axon terminals were evenly distributed throughout the IPL with the exception of a narrow sparsely labeled horizontal band in S2. Double immunostaining with PKC $\alpha$ (Fig. 2B,C) identified the large $\mathrm{RBC}$ varicosities close to the ganglion cell layer. The second layer of PKC $\alpha$-ir varicosities coincided with vGluT1 staining in S2. Next, we labeled for PKC $\alpha$ and G $\gamma 13$ (Fig. $2 E-K$ ). All $\mathrm{PKC} \alpha$-ir varicosities and terminals in S2, S4 and S5 were G $\gamma 13$ immunoreactive and thus are $\mathrm{ON} \mathrm{BC}$ terminals (Fig. $2 I-K$ ). The full extent of the IPL was revealed by differential interference contrast (DIC; Fig. $2 \mathrm{H}$ ) showing that the OFF sublayer takes up only $25 \%$ of the IPL (S1) and the ON sublayer takes up the remaining $75 \%$ of the IPL (S2-S5).

\section{Tristratified morphology of AII amacrine cells}

Mammalian AII amacrine cells usually have a bistratified morphology with distinct lobular appendages in the OFF sublayer of the IPL and finer arboreal dendrites in the ON sublayer (Vaney et al., 1991). AIIs are glycinergic ACs and contain calretinin in several species, including primates (Wässle et al., 1995), rabbits (Massey and Mills, 1999), and bats (Jeon et al., 2007). Therefore, we assessed the morphology of the microbat AII amacrine cells by DiI injections in vertical slices that were prelabeled for calretinin (Fig. $3 A-C)$. In all cases, the DiI-injected ACs showed a tristrati- fied morphology, i.e., dendrites of lobular appearance in S1 and finer dendrites running parallel to the retinal layers in S2 and S4 plus S5 (Fig. 3B). Figure 3E shows calretinin immunolabeling in C. perspicillata not only in AII cells but also in horizontal cells and one ganglion cell. Double labeling for calretinin and $\operatorname{PKC} \alpha$ revealed all $\mathrm{PKC} \alpha$-ir varicosities in close contact with calretinin-ir processes (Fig. 3F). To reveal whether AII cells receive synaptic input from RBCs via glutamatergic ribbon synapses, vertical sections were triple immunolabeled for calretinin, $\mathrm{PKC} \alpha$, and CtBP2 (Fig. 3G-I). CtBP2 labels the presynaptic ribbons within the axon terminals (Jusuf et al., 2006) and occurs in Figure $3 G$ as punctate labeling that is colocalized with the $\mathrm{PKC} \alpha$-ir varicosities in S2 and S4 plus S5 of the IPL. Additional labeling with calretinin revealed the ribbons in $\mathrm{PKC} \alpha$-ir varicosities next to their contact sites with the AII dendrites in S2 and S4 plus S5 (Fig. 3I).

\section{Glycine receptors are associated with AII processes and OFF cone bipolar cells}

The glycine receptor $\alpha 1$ subunit (GlyR $\alpha 1)$ is expressed at the glycinergic synapses between AII ACs and OFF cone BCs (SassoéPognetto et al., 1994; Grünert and Wässle, 1996). Similar to other mammalian retinae, GlyR $\alpha 1$ immunoreactivity in the microbat was found in large synaptic puncta in the outer IPL and smaller ones in the inner IPL (Fig. 4A,C). Double labeling for GlyR $\alpha 1$ and calretinin further validated the identification of microbat AII cells (Fig. $4 C, D$ ). The GlyR $\alpha 1$-ir puncta were localized mostly in S1 of the IPL (Fig. 4C). Several calretinin-ir varicose processes also were present in S1 of the IPL, resembling the typical morphology of AII lobular appendages. Superposition of the labels showed a close association between the GlyR $\alpha 1$ puncta and AII dendrites in the OFF sublayer (Fig. 4D). Next, we looked for cone BCs by immunolabeling for the calcium binding protein recov- 

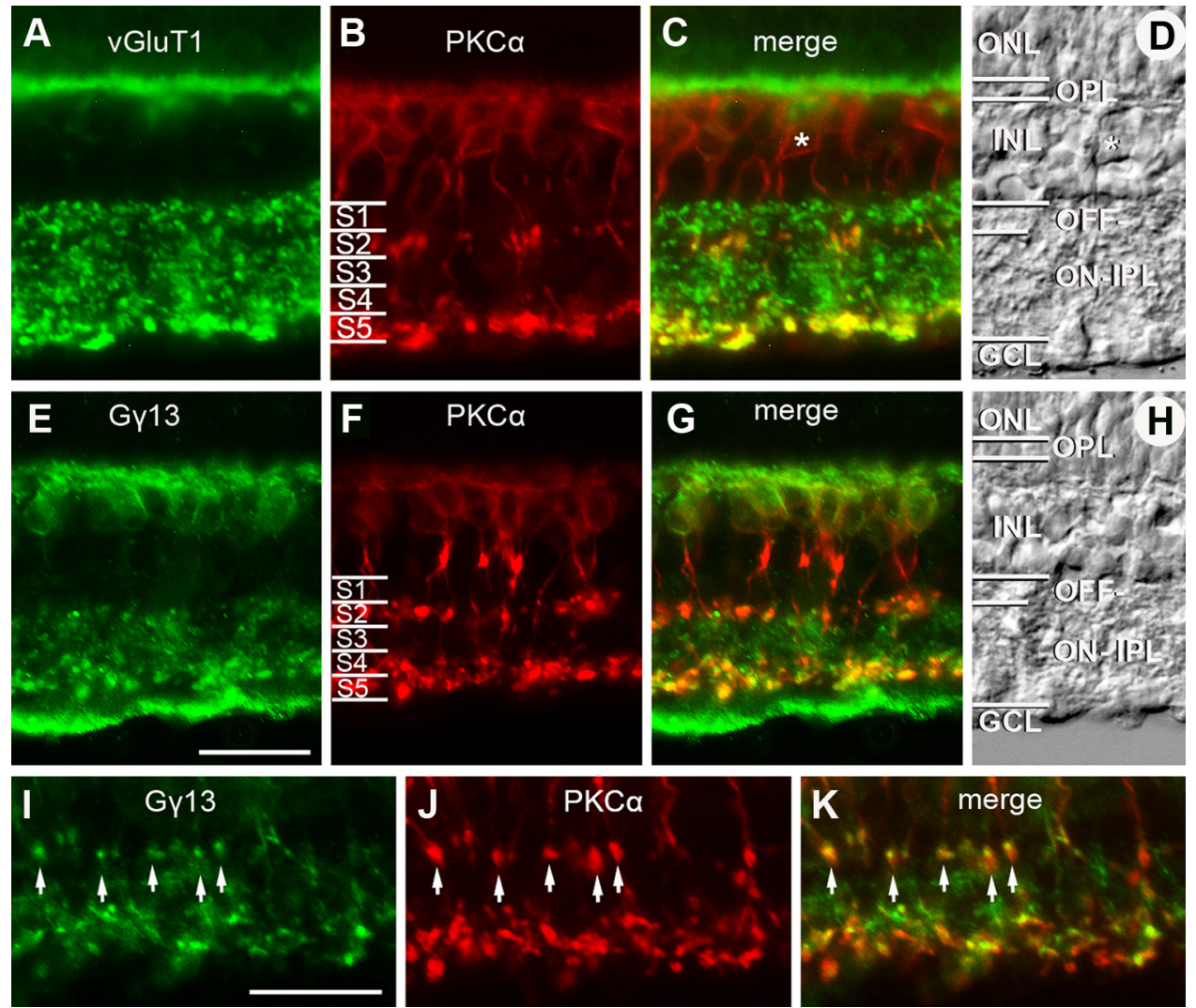

Figure 2. Vertical cryostat sections of C. perspicillata retina, double labeled for vGluT1 and PKC $\alpha(\boldsymbol{A}-\boldsymbol{C})$ or $\mathrm{G} \gamma 13$ and PKC $\alpha(\boldsymbol{E}-\boldsymbol{K})$. D, $\boldsymbol{H}$, Retinal layers of sections $\boldsymbol{C}$ and $\mathbf{G}$ with DIC optics (asterisks in $\boldsymbol{C}$ and $\boldsymbol{D}$ mark the same RBC). $\boldsymbol{A}$, vGluT1 is expressed in all BC axon terminals throughout the IPL and in all photoreceptor terminals in the OPL. $\boldsymbol{B}$, PKC $\alpha$ labels all RBCs with axon varicosities in S2 and in $\mathbf{S 4}$ plus $\$ 5$. C, Colocalization of both labels in $\mathbf{S 2}$ and $S 4$ plus $S 5$ is visible as yellow labeling. $\boldsymbol{E}$, G $\gamma 13$-ir cell bodies in the outer INL and axon terminals in the inner IPL (ON sublayer). $\boldsymbol{G}$, Colocalization of $G \gamma 13$ and PKC $\alpha$ in S2 and S4 plus S5. I-K, Double immunolabeling for $G \gamma 13$ and PKC $\alpha$ in the IPL at higher magnification. Colocalization is visible in S2 (arrows) and S4 plus S5. Scale bars: $\boldsymbol{A}-\boldsymbol{H}$ (in $\boldsymbol{E}), \boldsymbol{A}-\boldsymbol{K}($ in $\boldsymbol{I}), 20 \mu \mathrm{m} . \mathrm{GCL}$, Ganglion cell layer.

erin. Recoverin is a reliable marker for subsets of $\mathrm{OFF}$ and $\mathrm{ON}$ cone BCs in several species (Milam et al., 1993; Massey and Mills, 1996; Cuenca et al., 2002). In the microbat retina, there was a recoverin-ir population of OFF cone BCs stratifying in S1, and there were recoverin-ir axon terminals of ON bipolar cells in S4/S5 (Fig. 4E, K). Double labeling with PKC $\alpha$ and recoverin (Fig. 4F) showed no colocalization of the two markers, arguing for at least two cone $\mathrm{BC}$ types labeled by recoverin, an $\mathrm{ON}$ and an $\mathrm{OFF}$ cone BC. Triple labeling for recoverin, GlyR $\alpha 1$ and calretinin showed that the GlyR $\alpha 1$ puncta in S1 were closely associated with the recoverin-labeled OFF cone BC axon terminals (Fig. 4G) and AII dendrites (Fig. 4H). This supports the assumption that glycinergic transmission between AII ACs and OFF cone BCs is mediated by the GlyR $\alpha 1$ subunit also in the rod pathway of the bat retina.

\section{Connexin 36 is associated with AII processes and ON cone bipolar cells}

Electrical synapses between AII AC dendrites and ON cone BCs are a well established feature in mammals (Strettoi et al., 1992; Mills and Massey, 1995). Through these gap junctions, the AII ACs transmit light-ON signals to the ON cone BCs for further transmission to the ON ganglion cells. Cx36 was shown to be essential for transmission of the RBC ON signal from AII ACs to ON cone BCs (Deans et al., 2002). The AII ACs also are coupled among each other via Cx36-expressing gap junctions (Feigenspan et al., 2001; Deans et al., 2002). In the microbat retina, Cx36 labeling revealed gap junctions between calretinin-ir AII AC dendrites and recoverin-ir ON cone BC axon terminals in S4/S5 (Fig.
$4 I-M)$. Some of the Cx36-ir puncta at the AII cells in Figure $4 J$ probably represent AII-AII junctions, but the Cx36-ir puncta at $\mathrm{ON}$ cone $\mathrm{BC}$ dendrites (Fig. $4 K, M$ ) indicate that some of them are AII-BC junctions. Hence, we assume that this part of the rod pathway also exists in the microbat retina.

\section{GABAergic amacrine cells as potential synaptic partners of RBCs}

Since most amacrine cell contacts onto RBCs in mammalian retinae are GABAergic (Kim et al., 1998), we assessed whether microbat RBCs also express the $\rho$ subunit of the $\mathrm{GABA}_{\mathrm{C}}$ receptor. The $\mathrm{GABA}_{\mathrm{C}}$ receptor staining was homogeneously distributed throughout the IPL (Fig. 5A). In double-labeled vertical sections, $\mathrm{PKC} \alpha$-ir RBCs were decorated by many $\mathrm{GABA}_{\mathrm{C}}$-ir puncta, representing synaptic localization of the $\rho$ subunit (Fig. $5 C, D$ ). Many of the puncta were grouped into aggregates (Fig. 5C), and these aggregates were in register with axonal varicosities of $\mathrm{PKC} \alpha$-ir RBCs (Fig. 5D). In search for ACs using GABA as one of their transmitters, we labeled for NOS- and ChAT-expressing ACs (Fig. 5E-H). Double immunolabelings for PKC $\alpha$ in combination with ChAT or NOS should reveal how close the association between axonal varicosities of PKC $\alpha$-ir RBCs and GABAergic AC processes is. Since the dendrites of the ChAT-ir ACs stratified in S1 and S3, there was no overlap with the PKC $\alpha$-ir RBC axon terminals (Fig. 5G). Dendrites of NOS-ir ACs stratified at three levels in the IPL with two prominent strata located in S2 and S4 plus S5 and a finer one in S1 (Fig. 5E). Therefore, several NOS-ir profiles could be detected in close association with PKC $\alpha$-ir RBC 

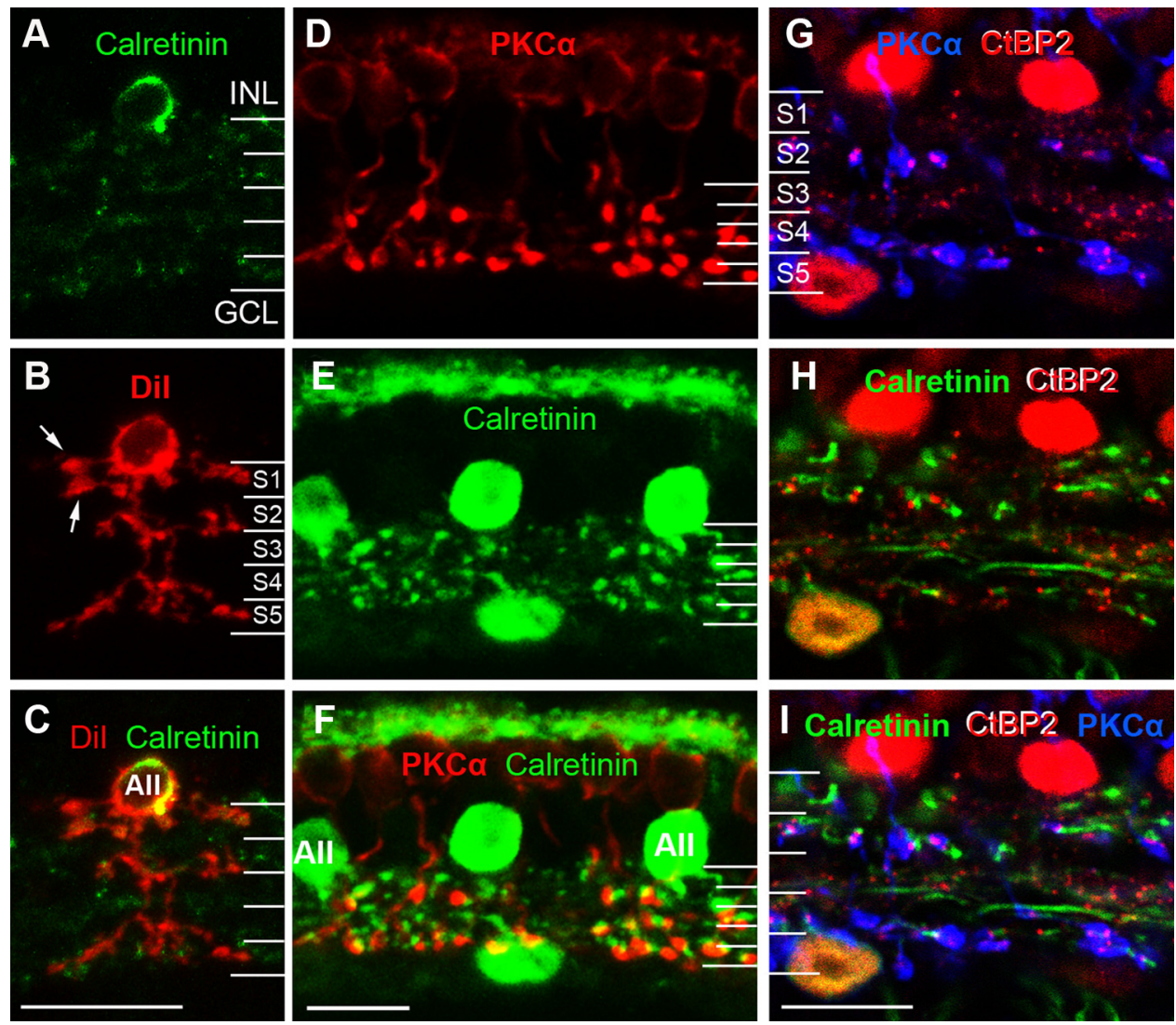

Figure 3. A-C, Dil-injected All amacrine cell in a vertical vibratome slice of C. perspicillata retina prelabeled for calretinin; a collapsed stack of 10 confocal optical slices of $1 \mu \mathrm{m}$ each. The IPL is divided into five strata, S1-S5. Presumed lobular appendages of the All AC in S1 are marked by arrows in $\boldsymbol{B}$. Dendrites of the All AC are obvious at two additional levels, in S2 and S5. D-I, Single confocal images of vertical cryostat sections of C. perspicillata retina labeled for PKC $\alpha$, calretinin, and CtBP2. D-F, Double immunolabeling for PKC $\alpha$ and calretinin. The calretinin label is present in horizontal cells and cells in the INL and ganglion cell layer (GCL). Throughout the IPL, numerous calretinin-ir All dendrites are labeled. The merge reveals a close association between PKC $\alpha$ - and calretinin-ir processes. Lobular appendages of All ACs are mostly out of focus. G-I, Triple immunolabeling for PKC $\alpha$, CtBP2, and calretinin. CtBP2-ir puncta in the OPL and IPL correspond to synaptic ribbons. Almost all somata in the INL are CtBP2 immunoreactive as well. RBC axon terminals in $S 2$, which contain ribbons (magenta; $\mathbf{G}, \boldsymbol{I}$ ), are in close association with calretinin-ir AC dendrites ( $\boldsymbol{H}$, I). Typical lobular appendages in $\mathbf{S 1}$ are visible too but slightly out of focus. Scale bars: $\boldsymbol{A}-\boldsymbol{C}$ (in $\boldsymbol{C}$ ), $20 \mu \mathrm{m} ; \boldsymbol{D}-\boldsymbol{F}$ (in $\boldsymbol{F}$ ), $\mathbf{G} \boldsymbol{I}$ (in $\boldsymbol{I}$ ), $10 \mu \mathrm{m}$.

axon terminals in S2 and S4 plus S5 (Fig. 5H), which makes GABAergic input onto RBCs very likely.

To further prove GABAergic input onto RBC axon terminals, we performed triple immunolabeling for $\mathrm{PKC} \alpha, \mathrm{GABA}_{\mathrm{C}}$, and NOS (Fig. $6 A-C^{\prime \prime}$ ). Double immunolabeling with $G_{A B A}$ and NOS (Fig. $6 B-B^{\prime \prime}$ ) revealed $\mathrm{GABA}_{\mathrm{C}}$-ir puncta in close association with NOS-ir profiles in S2 and S4 plus S5. In the merge (Fig. $6 C-C^{\prime \prime}$ ), aggregates of $\mathrm{PKC} \alpha-\mathrm{GABA}_{\mathrm{C}^{-}}$, and NOS-labeled profiles are obvious (arrows), making GABAergic input from NOS-ir ACs onto RBCs very likely. Triple immunolabeling for $\mathrm{PKC} \alpha$, CtBP2, and NOS (Fig. $6 D-F^{\prime \prime}$ ) showed that GABAergic input onto RBCs is very close to ribbon synapses and therefore may represent feedback synapses. In the merge (Fig. $6 F-F^{\prime \prime}$ ), numerous ribbons in RBC axon terminals in S2 and S4 plus S5 of the IPL (arrows) are closely associated with NOS-ir profiles, indicating $\mathrm{RBC}$ input. This is an arrangement not described in other mammals so far (Chun et al., 1999; Oh et al., 1999).

Figure 7 summarizes the rod pathway in the microbat retina schematically. Under scotopic conditions, the RBCs are stimulated (depolarized) by light and transmit this signal by glutamate onto AII ACs in the ON sublayer of the IPL, both in S2 and S4 plus S5. This ON signal is transmitted by the AII cells via signconserving gap junctions onto $\mathrm{ON}$ cone $\mathrm{BCs}$, which in turn are (very likely) connected to ON center ganglion cells. In parallel, the AII cells also feed the ON signal via sign-inverting glycinergic inhibitory synapses onto OFF cone BCs in S1, which in turn are (very likely) connected to OFF center ganglion cells. Additionally, the RBCs get GABAergic inhibitory input in the IPL, for example, via NOS amacrine cells at various strata in the ON sublayer.

\section{Discussion}

Bistratified morphology of rod bipolar cells in the microbat retina

The nocturnal microchiropteran bats are most famous for their echolocation, but vision also is an important sense for them (for review, see Eklöf, 2003).The eyes of microbats are small, and their retinae are rod dominated (Müller et al., 2009). Here we show that phyllostomid microbats also possess the two crucial elements of the mammalian rod pathway, rod bipolar cells and AII amacrine cells.

By PKC $\alpha$ immunostaining and DiI injections, we revealed the morphology of RBCs in microbat retina with their unusual bistratified axon terminal system (Fig. 1). We showed that RBC output occurs at both axonal levels in the IPL by identifying ribbon-containing presynaptic sites within the axonal varicosities of the PKC $\alpha$-labeled cells (Fig. 3G). This is unique among eutherian (placental) mammalian RBCs. The brushtail possum, a marsupial, also was shown to have eutherian-like monostratified RBCs (Young and Vaney, 1990). The same study described a multistratified PKC $\alpha$-ir BC in the echidna, a prototherian (egglaying) mammal. It remains to be shown whether this, in fact, is a $\mathrm{RBC}$. There are the rare exceptions of bistratified cone bipolar cell 


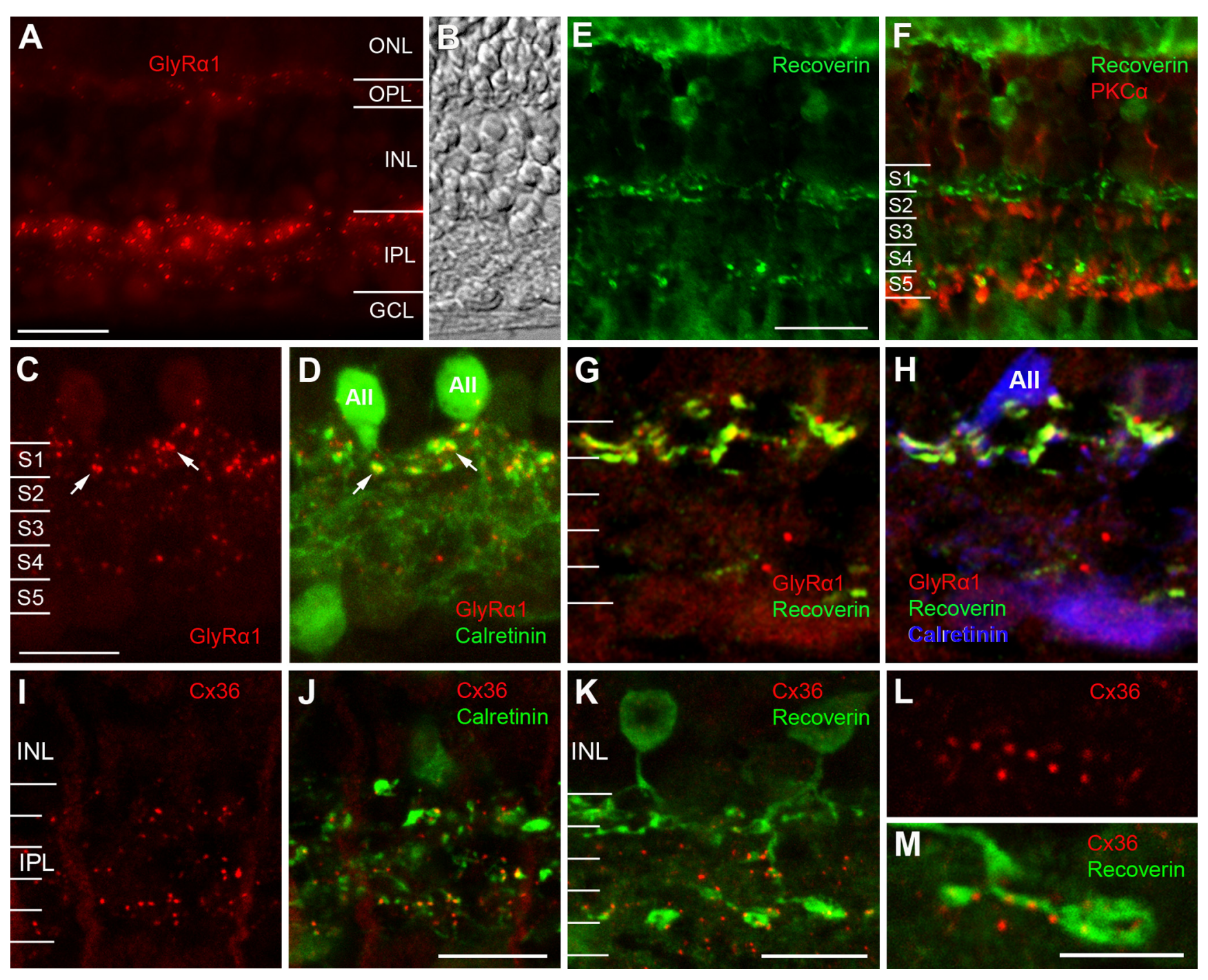

Figure 4. Fluorescence micrographs of vertical cryostat sections of C. perspicillata retina. $A$, Immunolabeling for the $\alpha 1$ subunit of the glycine receptor (GlyR $\alpha 1)$. GlyR $\alpha 1$-ir puncta are most numerous in the outer IPL (OFF sublayer), and smaller scattered puncta are found in the inner IPL (ON sublayer). In the OPL, sparsely distributed puncta are visible. GCL, Ganglion cell layer. $\boldsymbol{B}$, DIC optics of the section in $\boldsymbol{A}$ showing the retinal layers. $\boldsymbol{C}, \boldsymbol{D}$, Double labeling for calretinin and $G$ lyR $\alpha 1$. In the merge $(\boldsymbol{D})$, yellow profiles indicate $G$ ly $R \alpha 1$ puncta located at large calretinin-ir profiles in the outer part of the IPL (All lobular appendages; arrows in $\boldsymbol{C}$ and $\boldsymbol{D}$ ). $\boldsymbol{E}, \boldsymbol{F}$, Double labeling for PKC $\alpha$ and recoverin. $\boldsymbol{E}$, Recoverin is strongly expressed in photoreceptors in the ONL. In the INL a few recoverin-ir bipolar cell somata are visible. Their axons form a distinct plexus in $\mathrm{S1}$ of the IPL and a loose one in $S 4 / S 5$. $\boldsymbol{F}$, No colocalization of recoverin- and PKC $\alpha$-ir axon terminals is visible in the merge. $\boldsymbol{G}, \boldsymbol{H}$ Triple immunolabeling for calretinin, GlyR $\alpha$, and recoverin. $\mathbf{G}$, Recoverin-ir axon terminals in $\mathbf{S 1}$ are in close association with GlyR $\alpha$ 1-ir puncta. $\boldsymbol{H}$, In the merge of all three labels, calretinin-ir lobular appendages are in close association with recoverin-ir axon terminals indicating glycinergic input from the All AC to the OFF cone BC. $I$, Immunolabeling for $C \times 36$, a gap junction protein. $C \times 36$-ir puncta are most numerous in the inner IPL.J, Double labeling for $\mathrm{C} \times 36$ and calretinin. Almost all $\mathrm{C} \times 36$-ir puncta associate with calretinin-ir All dendrites. $\boldsymbol{K}$, Double immunolabeling for $\mathrm{C} \times 36$ and recoverin . Cx36-ir puncta decorate the axon terminals of recoverin-ir $0 \mathrm{~N}$ cone $B C S$. $L, M$, Higher magnification of another recoverin-ir cone $B C$ axon terminal in $S 4 / S 5$, decorated with $C \times 36$-ir puncta. Scale bars: $\boldsymbol{A}, \boldsymbol{B}$ (in $\boldsymbol{A}), 20 \mu \mathrm{m} ; \boldsymbol{C}-\boldsymbol{K}$ (in $\boldsymbol{C}, \boldsymbol{E}, \boldsymbol{J}, \boldsymbol{K}), 10 \mu \mathrm{m} ; \boldsymbol{L}, \boldsymbol{M}$ (in $(\boldsymbol{M}), 5 \mu \mathrm{m}$.

types in primates and ground squirrels (Mariani, 1983; Linberg et al., 1996). In the retina of nonmammalian vertebrates, bistratified or even multistratified BCs are more common, but there is no homolog of the mammalian RBC among them [carp (Scholes, 1975), turtle (Ammermüller and Kolb, 1995)].

The functional partition of the IPL into structurally separated $\mathrm{ON}$ and OFF sublayers can be visualized by vGluT1 and G $\gamma 13$ immunocytochemistry (Ghosh et al., 2004). In the retina of $C$. perspicillata, G $\gamma 13$ immunoreactivity labeled the inner $75 \%$ of the IPL thickness (S2-S5; Fig. 2), leaving only 25\% for the OFF sublayer. All PKC $\alpha$-ir varicose axon terminals were located within the G $\gamma 13$-ir ON sublayer of the IPL (Fig. $2 I-K$ ). Hence, the output of the microbat's bistratified RBCs is confined to the ON sublayer, which is consistent with the general rule that mammalian RBCs are functional ON cells. The $25 \%$ versus $75 \%$
OFF/ON partition of the microbat's IPL is very unusual among mammals. In mouse (Ghosh et al., 2004) and rabbit (McGillem and Dacheux, 2001), the OFF sublayer makes up $40 \%$ of the IPL; in monkey, it makes up 45\% (Grünert et al., 1994). Rod-to-cone ratios in microbat and mouse retinae are comparable [microbats, 2-5\% (Müller et al., 2009); mouse, 3\% (Jeon et al., 1998)], and both are nocturnal species. Possibly the requirements of night vision and orientation tasks during nocturnal flights may have favored a more complex processing of ON signals in the IPL of the microbat retina.

Tristratified AII amacrine cells as postsynaptic partners of bistratified rod bipolar cells

A crucial element in the mammalian rod pathway is the bistratified AII amacrine cell that receives input from the RBC and 

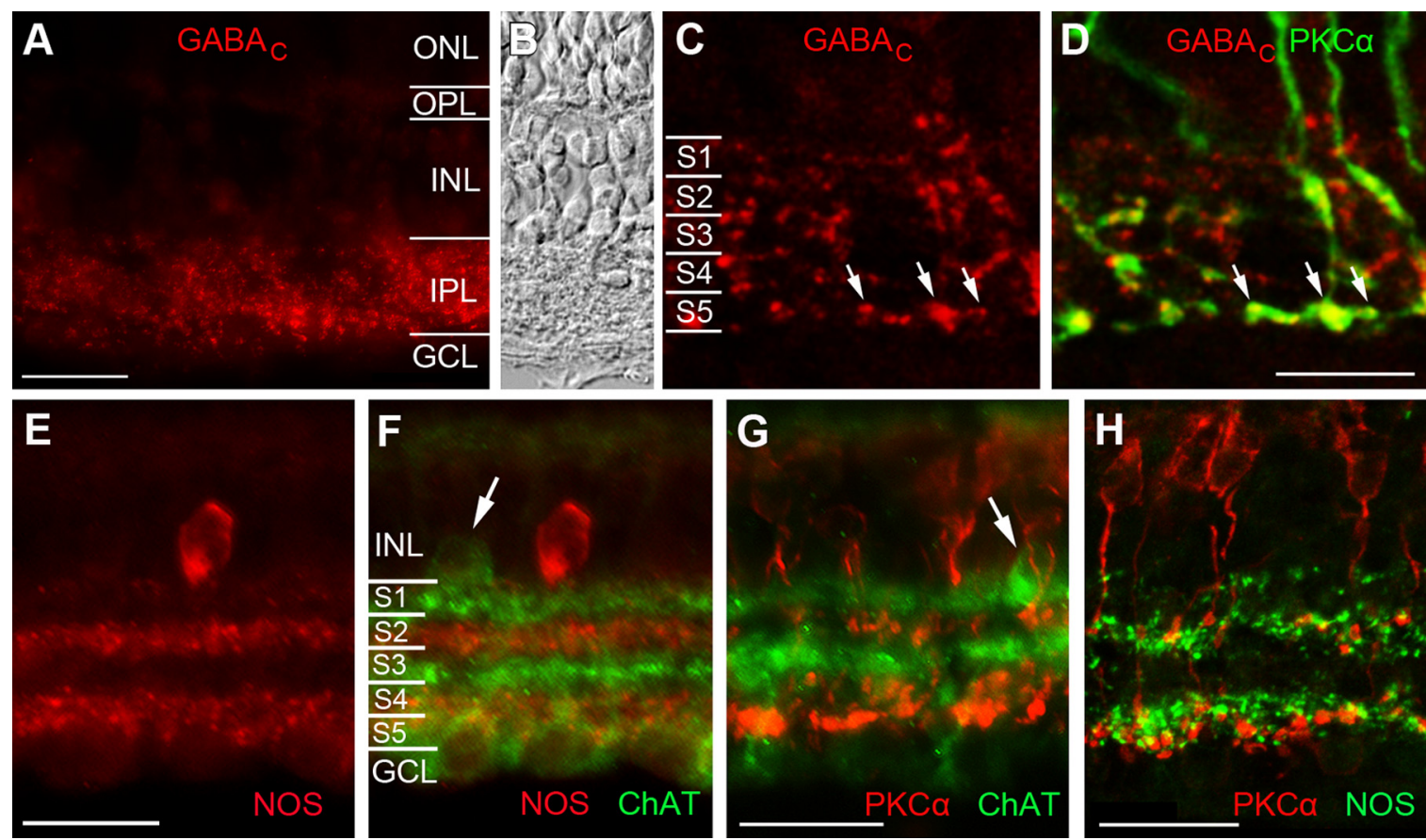

Figure 5. Fluorescence micrographs of vertical cryostat sections of $C$. perspicillata retina. $A$, Immunolabeling for $G A B A_{C}$ receptors. There is strong punctate labeling throughout the IPL. $B$, DIC optics of the section in $\boldsymbol{A}$ showing the retinal layers. $\boldsymbol{C}, \boldsymbol{D}$, Double labeling for $\mathrm{GABA}_{C}$ and $\mathrm{PKC} \alpha$. In the merge $(\boldsymbol{D})$, yellow profiles indicate $G A B A_{C}$ puncta located at the PKC $\alpha$-ir RBC axon terminals (arrows). $E$, $F$, Double immunolabeling for NOS and ChAT. $\boldsymbol{E}$, In the innermost INL, a NOS-ir AC soma is visible. NOS-ir processes stratify at three levels in the IPL, and the two prominent strata are located in S2 and S4 plus S5, the finer one in S1.F, The merge shows the typical appearance of ChAT-ir ACs with their processes stratifying at two levels in the IPL, the outer one in the 0FF-lamina (S1) and the inner one in the ON-lamina (S3). There is hardly any overlap between the NOS and the ChAT AC dendrites in the IPL and hence no colocalization. G, Double labeling for PKC $\alpha$ and ChAT. Since the dendrites of the ChAT-ir ACs stratify in S1 and S3, no overlap with the PKC $\alpha$-ir RBC axon terminals is visible. Arrows in $\boldsymbol{F}$ and $\boldsymbol{G}$ mark ChAT-ir somata. $\boldsymbol{H}$, Double labeling for PKC $\alpha$ and NOS. Since dendrites of the NOS-ir $A C s$ stratify in $S 2$ and $S 4$ plus $S 5$, several NOS-ir profiles can be detected in close association with PKC $\alpha$-ir RBC axon terminals, which makes $G A B A$ ergic input to RBCs very likely. Scale bars: $A, B$ (in $A$ ), $E, G, H, 20 \mu \mathrm{m} ; \boldsymbol{C}, \boldsymbol{D}$ (in $\boldsymbol{D}), 10 \mu \mathrm{m}$.

makes output onto $\mathrm{ON}$ and OFF cone BCs (for review, see Bloomfield and Dacheux, 2001). Antibodies against calretinin label AII ACs in rabbit (Massey and Mills, 1999) and macaque (Wässle et al., 1995). Recently, a study in the microbat Rhinolophus ferrumequinum showed calretinin-ir ACs with typical AIIlike morphology (Jeon et al., 2007). Our calretinin labeling in $C$. perspicillata showed a similar pattern, and DiI injections revealed a tristratified morphology of the AII cells with lobular appendages in S1 and finer dendrites stratifying in S2 and S4 plus S5 (Fig. $3 A-C)$. We identified ribbon-containing output synapses of RBCs onto the putative AII cells by confocal imaging and found evidence for numerous synaptic contacts between the two cell types at both AII stratification levels within the ON sublayer of the IPL (Fig. $3 H, I$ ). Since this morphology was found consistently throughout the retina it does not represent odd ectopic synaptic contacts but the blueprint of the microbat retina. Obviously, the ON signaling of RBCs onto ON cone BCs via the AII ACs is strengthened by a second synaptic output layer in the IPL. Again, this is unique in the mammalian rod pathway.

\section{AII amacrine cells synapse onto OFF and ON cone bipolar cells}

In the mammalian retina, it is well established that the rod ON signal is transmitted via electrical synapses (gap junctions) from AII AC dendrites onto ON cone BCs (Bloomfield and Dacheux, 2001; Deans et al., 2002). In the microbat retina, double immunolabelings for $\mathrm{Cx} 36$ and calretinin or recoverin provided evidence for electrical synapses between AII AC dendrites and ON cone BCs. Hence, this crucial element of the rod pathway also exists in the microbat.
AII ACs also feed the ON signal via inhibitory synapses onto OFF cone BCs. Sassoè-Pognetto et al. (1994) showed that the glycine receptor subunit $\alpha 1$ is expressed at glycinergic synapses between AII ACs and OFF cone BCs. We found comparable synaptic contacts in the microbat. Recoverin-ir axon terminals of OFF cone BCs stratify in S1 of the IPL, are well equipped with GlyR $\alpha 1$-ir puncta, and are in close association with calretinin-ir AII dendrites (Fig. 4G,H). The anatomical evidence shown here is that glycinergic transmission between AII ACs and OFF cone BCs is mediated by the GlyR $\alpha 1$ subunit in the rod pathway of the microbat retina too, and it may be assumed that these are the glycinergic synapses through which the rod signals pass from the lobular processes of AII ACs to OFF cone BCs and subsequently to OFF ganglion cells.

GABAergic amacrine cells synapse onto the bistratified rod bipolar cells at two synaptic levels

At the RBC axon terminal, the AII AC constitutes one member of the postsynaptic dyad; the other member is a GABAergic AC known as A17 in cat (Nelson and Kolb, 1985) and as indoleamine-accumulating AC in rabbit (Strettoi et al., 1990). The latter cell type makes reciprocal synapses back onto the RBC axon terminal. Several other amacrine cells provide additional GABAergic input onto RBC axon terminals via nonreciprocal synapses (Sterling and Lampson, 1986). GABAergic input onto $\mathrm{RBC}$ terminals is mediated by distinct populations of $\mathrm{GABA}_{\mathrm{A}}$ and $\mathrm{GABA}_{\mathrm{C}}$ receptors (Fletcher and Wässle, 1999; Chávez et al., 2010). In microbat, we found similar clusters of $\mathrm{GABA}_{C} \mathrm{Rs}$ at the $\mathrm{RBC}$ axon terminals both in S2 and S4 plus S5. Furthermore, 

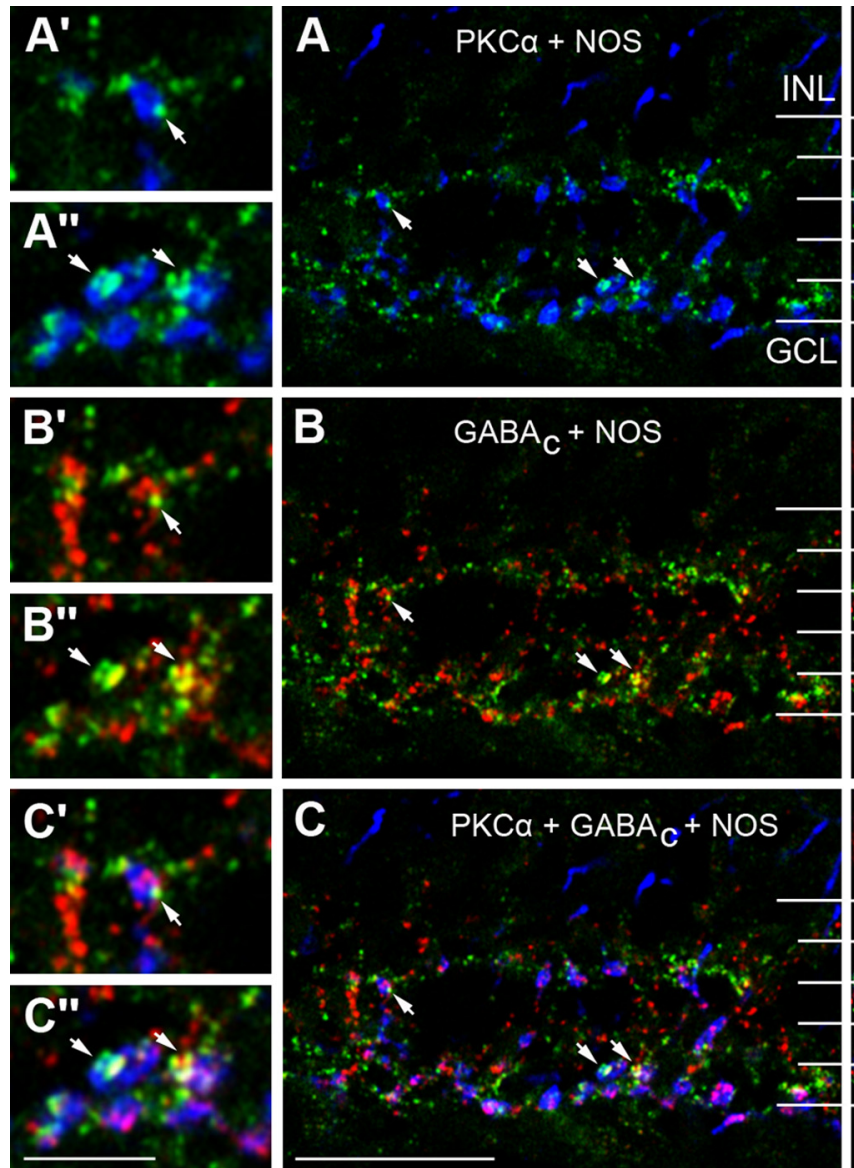
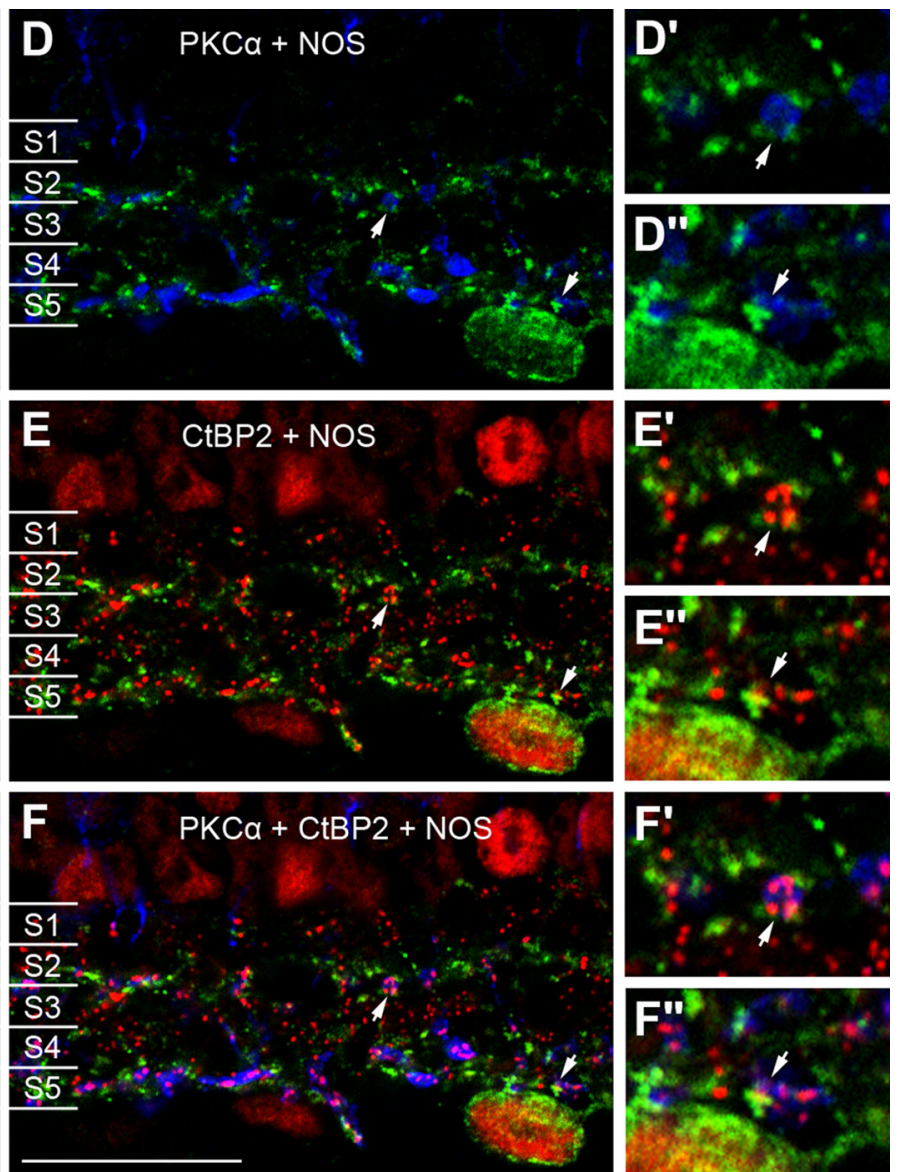
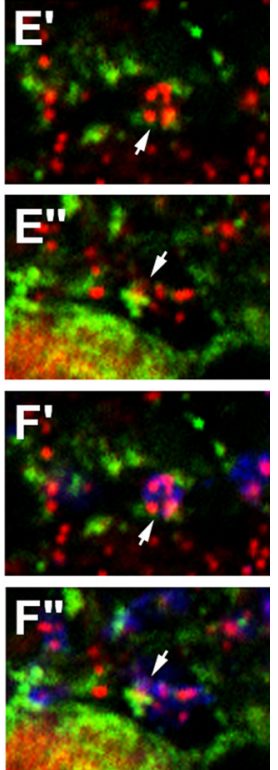

Figure 6. Synaptic interaction between NOS ACs and RBCs. $\boldsymbol{A}-\boldsymbol{F}^{\prime \prime}$, Single confocal images of triple immunolabeling for PKC $\alpha$ (blue), GABA $\left(\right.$ red), and NOS (green) (A-C $\left.\boldsymbol{C}^{\prime \prime}\right)$ and for PKC $\alpha$ (blue), CtBP2 (red), and NOS (green) $\left(\boldsymbol{D}-\boldsymbol{F}^{\prime \prime}\right) . \boldsymbol{A}, \boldsymbol{D}$, Several PKC $\alpha$-ir RBC axon terminals (blue) can be detected in close association with N0S-ir profiles in S2 (enlarged in $\boldsymbol{A}^{\prime}, \boldsymbol{D}^{\prime}$ ) and S4 plus $S 5$ (enlarged in $\boldsymbol{A}^{\prime \prime}, \boldsymbol{D}^{\prime \prime}$ ). Double immunolabeling with GABA ${ }_{C}$ and NOS $\left(\boldsymbol{B}-\boldsymbol{B}^{\prime \prime}\right)$ reveals $\mathrm{GABA}_{\mathrm{C}}$-ir puncta in close association with N0S-ir profiles in $\mathbf{S 2}$ and $S 4$ plus $S 5$ (arrows). $\boldsymbol{C}-\boldsymbol{C}^{\prime \prime}$, In the merge, aggregates of green, blue, and magenta label are obvious, making GABAergic input from the NOS-ir ACs to RBCs very likely. Double immunolabeling with CtBP2 and NOS

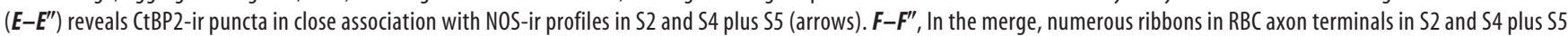
of the IPL (arrows) are closely associated with NOS-ir profiles, indicating synaptic input. Scale bars: $\boldsymbol{A}-\boldsymbol{C}$ (in $\boldsymbol{C}$ ), $\boldsymbol{D}-\boldsymbol{F}$ (in $\boldsymbol{F}$ ), $20 \mu \mathrm{m} ; \boldsymbol{A}^{\prime}-\boldsymbol{F}^{\prime \prime}$ (in $\boldsymbol{C}^{\prime \prime}$ ), $5 \mu \mathrm{m}$.

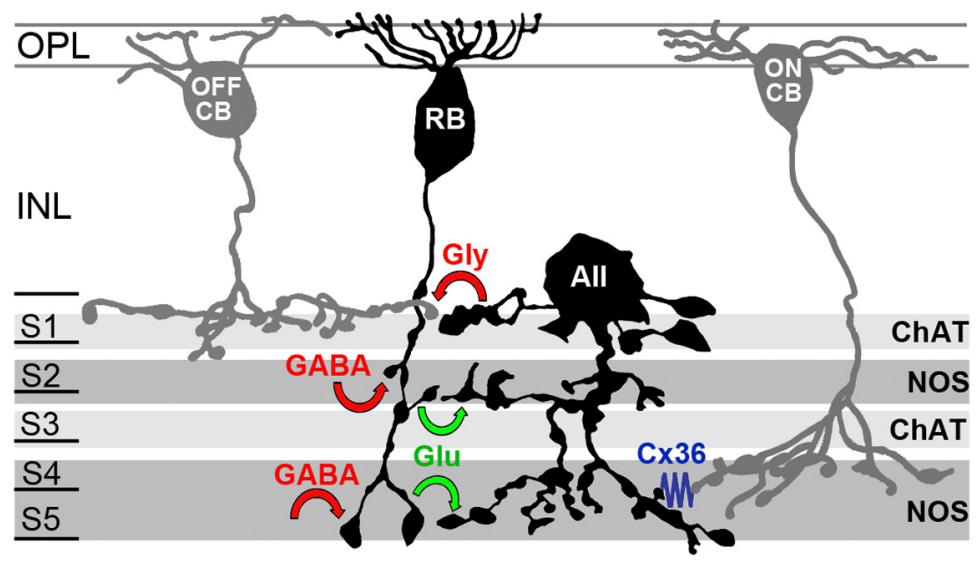

Figure 7. Scheme of the rod pathway in C. perspicillata. Line drawings of Dil-injected cells prelabeled for PKC $\alpha$ (RBC), calretinin (All amacrine cell), and recoverin (OFF and ON CB, cone bipolar cells) are shown. They were reconstructed from vertical retinal slices after intracellular injections. In the IPL (S1-S5), the immunoreactive plexus of ChAT and NOS ACs are marked as bars in different shades of gray. The RB makes glutamatergic synapses onto the All AC in $\mathrm{S} 4$ plus $\mathrm{S} 5$ and $\mathrm{S} 2$ of the IPL, transmitting a light-ON signal. In S1, lobular appendages of the All AC make glycinergic (sign-inverting) output onto the OFF CB. In $S 4 / S 5$, the light- $0 \mathrm{~N}$ signal is transmitted from the All AC onto the $\mathrm{ON}$ cone $\mathrm{BC}$ via (sign-conserving) gap junctions, labeled by connexin36 (Cx36). Dendrites of NOS-ir putative GABAergic ACs make feedback onto the RB. immunolabeling for $\mathrm{GABA}_{\mathrm{A}} \mathrm{R} \alpha 1$ also revealed colocalization with $\mathrm{RBC}$ axon terminals (data not shown).

Starburst ACs synthesize and release both GABA and acetylcholine when depolarized (O'Malley and Masland, 1989) and are labeled by antibodies against ChAT in a variety of mammalian species (Voigt, 1986; Famiglietti and Tumosa, 1987; Schmidt et al., 1987; Rodieck and Marshak, 1992). They occur as matching populations of displaced and nondisplaced ACs, and their dendrites form two narrow strata in the $\mathrm{ON}$ and OFF sublayer of the IPL. In microbat, two subtypes of ChAT-ir ACs could be detected as well but were ruled out as potential candidates for contacting $\mathrm{RBC}$ axon terminals because their stratification levels differed (Fig. 5G).

In rat and rabbit retinae, NOS ACs are a subpopulation of GABAergic ACs (Oh et al., 1998). In rat, mouse, guinea pig, rabbit, and cat, NOS-expressing ACs were 
labeled by antibodies against a C-terminal fragment of the rat brain NOS (Kim et al., 1999). In microbat, NOS-ir dendrites costratify with RBC axon terminals in S2 and S4 plus S5 (Fig. $5 \mathrm{H}$ ) and therefore seem to be promising candidates for contacting RBCs. Triple immunolabeling for $\mathrm{PKC} \alpha$, NOS, and either $\mathrm{GABA}_{\mathrm{C}}$ or CtBP2 provided additional evidence for the close apposition of NOS-ir profiles with ribbon puncta or $\mathrm{GABA}_{\mathrm{C}}$-ir puncta on RBC axon terminals (Fig. 6). This makes GABAergic input from NOS-ir ACs onto RBCs very likely. The involvement of NOS-ir ACs in the RBC dyad complex is a novel observation. EM studies in rat and guinea pig did not provide any evidence for NOS-ir ACs in direct contact with RBCs (Chun et al., 1999; Oh et al., 1999). Additional studies are needed to elucidate whether in the microbat retina the NOS-ir ACs form reciprocal and/or nonreciprocal synapses onto RBCs. Therefore, we do not know yet whether the NOS-ir AC represents a further GABAergic AC feeding back onto RBCs in addition to an A17 homolog, or whether it completely replaces an A17 homolog. Nevertheless, the present data indicate that the common mammalian dyad arrangement at $\mathrm{RBC}$ axons with GABAergic feedback synapses is also present in microbats.

In summary, our data demonstrate that the rod pathway of the microbat retina largely conforms to the general mammalian blueprint (Bloomfield and Dacheux, 2001) but shows some batspecific characteristics. One peculiarity is the bistratified organization of the RBC output that also seems to directly affect the morphology of AII AC dendrites. The other characteristic is that in the bat, the ON sublayer occupies a markedly larger proportion of the IPL thickness than in other mammals. This argues for a bat-specific weighting in the processing of light and dark stimuli. Most likely, in the bats' predominantly dark environment, ON signals have greater importance for contrast perception. We assume that this is associated with the importance of visual orientation and navigation tasks during foraging, homing, and predator avoidance (Altringham and Fenton, 2003; Eklöf and Jones, 2003). In this context, it should be noted that microbats are extraordinarily fast and elegant flyers, which makes them unique among mammals and may demand special visual capabilities.

\section{References}

Altringham JD, Fenton MB (2003) Sensory ecology and communication in the chiroptera. In: Bat ecology (Kunz TH, Fenton MB, eds), pp 90-127. Chicago: The University of Chicago Press.

Ammermüller J, Kolb H (1995) The organization of the turtle inner retina. I. ON- and OFF-center pathways. J Comp Neurol 358:1-34. CrossRef Medline

Barton RA, Harvey PH (2000) Mosaic evolution of brain structure in mammals. Nature 405:1055-1058. CrossRef Medline

Barton RA, Purvis A, Harvey PH (1995) Evolutionary radiation of visual and olfactory brain systems in primates, bats and insectivores. Philos Trans R Soc Lond B Biol Sci 348:381-392. CrossRef Medline

Bloomfield SA, Dacheux RF (2001) Rod vision: pathways and processing in the mammalian retina. Prog Ret Eye Res 20:351-384. CrossRef

Chávez AE, Grimes WN, Diamond JS (2010) Mechanisms underlying lateral GABAergic feedback onto rod bipolar cells in rat retina. J Neurosci 30:2330-2339. CrossRef Medline

Chun MH, Oh SJ, Kim IB, Kim KY (1999) Light and electron microscopical analysis of nitric oxide synthase-like immunoreactive neurons in the rat retina. Vis Neurosci 16:379-389. Medline

Cuenca N, Deng P, Linberg KA, Lewis GP, Fisher SK, Kolb H (2002) The neurons of the ground squirrel retina as revealed by immunostains for calcium binding proteins and neurotransmitters. J Neurocytol 31:649666. CrossRef Medline

Dacheux RF, Raviola E (1986) The rod pathway in the rabbit retina: a depolarizing bipolar and amacrine cell. J Neurosci 6:331-345. Medline

Deans MR, Volgyi B, Goodenough DA, Bloomfield SA, Paul DL (2002)
Connexin36 is essential for transmission of rod-mediated visual signals in the mammalian retina. Neuron 36:703-712. CrossRef Medline

Eklöf J (2003) Vision in echolocating bats. PhD thesis, Göteborg University (http://www.fladdermus.net/thesis.htm).

Eklöf J, Jones G (2003) Use of vision in prey detection by brown long-eared bats, Plecotus auritus. Anim Behav 66:949-953. CrossRef

Enz R, Brandstätter JH, Wässle H, Bormann J (1996) Immunocytochemical localization of the $\mathrm{GABA}_{\mathrm{C}}$ receptor subunits in the mammalian retina. J Neurosci 16:4479-4490. Medline

Famiglietti EV Jr, Kolb H (1975) A bistratified amacrine cell and synaptic circuitry in the inner plexiform layer of the retina. Brain Res 84:293-300. CrossRef Medline

Famiglietti EV, Tumosa N (1987) Immunocytochemical staining of cholinergic amacrine cells in rabbit retina. Brain Res 413:398-403. CrossRef Medline

Feigenspan A, Teubner B, Willecke K, Weiler R (2001) Expression of neuronal connexin36 in AII amacrine cells of the mammalian retina. J Neurosci 21:230-239. Medline

Fletcher EL, Wässle H (1999) Indoleamine-accumulating amacrine cells are presynaptic to rod bipolar cells through $\mathrm{GABA}_{\mathrm{C}}$ receptors. J Comp Neurol 413:155-167. CrossRef Medline

Ghosh KK, Bujan S, Haverkamp S, Feigenspan A, Wässle H (2004) Types of bipolar cells in the mouse retina. J Comp Neurol 469:70-82. CrossRef Medline

Greferath U, Grünert U, Wässle H (1990) Rod bipolar cells in the mammalian retina show protein kinase C-like immunoreactivity. J Comp Neurol 301:433-442. CrossRef Medline

Griffin DR (1970) Migration and homing of bats. In: Biology of bats (Wimsatt WA, ed), pp 233-264. New York: Academic.

Grünert U, Wässle H (1996) Glycine receptors in the rod pathway of the macaque monkey retina. Vis Neurosci 13:101-115. CrossRef Medline

Grünert U, Martin PR, Wässle H (1994) Immunocytochemical analysis of bipolar cells in the macaque monkey retina. J Comp Neurol 348:607-627. CrossRef Medline

Huang L, Max M, Margolskee RF, Su H, Masland RH, Euler T (2003) G protein subunit $\mathrm{G}$ gamma 13 is coexpressed with $\mathrm{G}$ alpha $\mathrm{o}$, $\mathrm{G}$ beta 3 , and G beta 4 in retinal ON bipolar cells. J Comp Neurol 455:1-10. CrossRef Medline

Jeon CJ, Strettoi E, Masland RH (1998) The major cell populations of the mouse retina. J Neurosci 18:8936-8946. Medline

Jeon YK, Kim TJ, Lee JY, Choi JS, Jeon CJ (2007) AII amacrine cells in the inner nuclear layer of bat retina: identification by parvalbumin immunoreactivity. Neuroreport 18:1095-1099. CrossRef Medline

Jusuf PR, Martin PR, Grünert U (2006) Synaptic connectivity in the midgetparvocellular pathway of primate central retina. J Comp Neurol 494:260 274. CrossRef Medline

Kao YH, Sterling P (2003) Matching neural morphology to molecular expression: single cell injection following immunostaining. J Neurocytol 32:245-251. CrossRef Medline

Kim IB, Lee MY, Oh S, Kim KY, Chun M (1998) Double-labeling techniques demonstrate that rod bipolar cells are under GABAergic control in the inner plexiform layer of the rat retina. Cell Tissue Res 292:17-25. CrossRef Medline

Kim IB, Lee EJ, Kim KY, Ju WK, Oh SJ, Joo CK, Chun MH (1999) Immunocytochemical localization of nitric oxide synthase in the mammalian retina. Neurosci Lett 267:193-196. CrossRef Medline

Linberg KA, Suemune S, Fisher SK (1996) Retinal neurons of the California ground squirrel, Spermophilus beecheyi: a Golgi study. J Comp Neurol 365:173-216. CrossRef Medline

Mariani AP (1983) Giant bistratified bipolar cells in monkey retina. Anat Rec 206:215-220. CrossRef

Massey SC, Mills SL (1996) A calbindin-immunoreactive cone bipolar cell type in the rabbit retina. J Comp Neurol 366:15-33. CrossRef Medline

Massey SC, Mills SL (1999) Antibody to calretinin stains AII amacrine cells in the rabbit retina: double-label and confocal analyses. J Comp Neurol 411:3-18. CrossRef Medline

McGillem GS, Dacheux RF (2001) Rabbit cone bipolar cells: correlation of their morphologies with whole-cell recordings. Vis Neurosci 18:675-685. CrossRef Medline

Milam AH, Dacey DM, Dizhoor AM (1993) Recoverin immunoreactivity in mammalian cone bipolar cells. Vis Neurosci 10:1-12. CrossRef Medline Mills SL, Massey SC (1995) Differential properties of two gap junctional 
pathways made by AII amacrine cells. Nature 377:734-737. CrossRef Medline

Müller B, Glösmann M, Peichl L, Knop GC, Hagemann C, Ammermüller J (2009) Bat eyes have ultraviolet-sensitive cone photoreceptors. PLoS One 4:e6390. CrossRef Medline

Nelson R, Kolb H (1985) A17: a broad-field amacrine cell in the rod system of the cat retina. J Neurophysiol 54:592-614. Medline

Oh SJ, Kim IB, Lee MY, Chun MH, Chung JW (1998) NOS-like immunoreactive neurons express GABA-like immunoreactivity in rabbit and rat retinae. Exp Brain Res 120:109-113. CrossRef Medline

Oh SJ, Kim HI, Kim IB, Kim KY, Huh W, Chung JW, Chun MH (1999) Morphology and synaptic connectivity of nitric oxide synthaseimmunoreactive neurons in the guinea pig retina. Cell Tissue Res 297: 397-408. CrossRef Medline

O'Malley DM, Masland RH (1989) Co-release of acetylcholine and $\gamma$-aminobutyric acid by a retinal neuron. Proc Natl Acad Sci U S A 86: 3414-3418. CrossRef Medline

Puller C, Ondreka K, Haverkamp S (2011) Bipolar cells of the ground squirrel retina. J Comp Neurol 519:759-774. CrossRef Medline

Ramón y Cajal S (1893) La rétine des vertébrés. Cellule 9:121-225.

Rodieck RW, Marshak DW (1992) Spatial density and distribution of choline acetyltransferase immunoreactive cells in human, macaque, and baboon retinas. J Comp Neurol 321:46-64. CrossRef Medline

Saito T (1987) Physiological and morphological differences between ONand OFF-center bipolar cells in the vertebrate retina. Vis Res 27:135-142. CrossRef Medline

Sassoè-Pognetto M, Wässle H, Grünert U (1994) Glycinergic synapses in the rod pathway of the rat retina: cone bipolar cells express the alpha 1 subunit of the glycine receptor. J Neurosci 14:5131-5146. Medline
Schmidt M, Humphrey MF, Wässle H (1987) Action and localization of acetylcholine in the cat retina. J Neurophysiol 58:997-1015. Medline

Scholes JH (1975) Colour receptors, and their synaptic connexions, in the retina of a cyprinid fish. Philos Trans R Soc Lond B Biol Sci 270:61-118. CrossRef Medline

Sterling P, Lampson LA (1986) Molecular specificity of defined types of amacrine synapse in cat retina. J Neurosci 6:1314-1324. Medline

Strettoi E, Dacheux RF, Raviola E (1990) Synaptic connections of rod bipolar cells in the inner plexiform layer of the rabbit retina. J Comp Neurol 295:449-466. CrossRef Medline

Strettoi E, Raviola E, Dacheux RF (1992) Synaptic connections of the narrow-field, bistratified rod amacrine cell (AII) in the rabbit retina. J Comp Neurol 325:152-168. CrossRef Medline

Studholme KM, Yazulla S, Phillips CJ (1987) Interspecific comparisons of immunohistochemical localization of retinal neurotransmitters in four species of bats. Brain Behav Evol 30:160-173. CrossRef Medline

Suthers RA (1970) Vision, olfaction, taste. In: Biology of bats (Wimsatt WA, eds), pp 265-304. New York: Academic.

Vaney DI, Gynther IC, Young HM (1991) Rod-signal interneurons in the rabbit retina: 2. AII amacrine cells. J Comp Neurol 310:154-169. CrossRef Medline

Voigt T (1986) Cholinergic amacrine cells in the rat retina. J Comp Neurol 248:19-35. CrossRef Medline

Wässle H, Grünert U, Chun MH, Boycott BB (1995) The rod pathway of the macaque monkey retina: identification of AII-amacrine cells with antibodies against calretinin. J Comp Neurol 361:537-551. CrossRef Medline

Young HM, Vaney DI (1990) The retinae of Prototherian mammals possess neuronal types that are characteristic of non-mammalian retinae. Vis Neurosci 5:61-66. CrossRef Medline 